\title{
Managing Shipping Companies, the Way Their Pioneer Managers Did: The Case-Study of Stavros Niarchos, 1909-1996
}

\author{
Alexandros M. Goulielmos ${ }^{1,2}$ \\ ${ }^{1}$ Faculty of Maritime and Industrial Studies, Department of Maritime Studies, University of Piraeus, Piraeus, Greece \\ ${ }^{2}$ Transport and Logistics Department, Business College of Athens, Athens, Greece \\ Email: ag@unipi.gr,am.goulielmos@hotmail.com, agoulielmos@bca.edu.gr
}

How to cite this paper: Goulielmos, A. M. (2021). Managing Shipping Companies, the Way Their Pioneer Managers Did: The Case-Study of Stavros Niarchos, 1909-1996. Modern Economy, 12, 878-902. https://doi.org/10.4236/me.2021.124044

Received: March 9, 2021

Accepted: April 26, 2021

Published: April 29, 2021

Copyright () 2021 by author(s) and Scientific Research Publishing Inc. This work is licensed under the Creative Commons Attribution International License (CC BY 4.0).

http://creativecommons.org/licenses/by/4.0/ (c) (i) Open Access

\begin{abstract}
Present, and future, managers of shipping companies have a lot to learn from their past colleagues. Students of the shipping industry always ask: How did Niarchos build such a fortune so as to leave $\$ 400 \mathrm{~m}$ upon his death? This is a third paper, presenting the business life of the late shipowner Stavros Niarchos, another "golden" Greek. He conceived the value of vertical integration in business, first applied by the Japanese. He established a ship-owning company, a shipyard, and a steel mill. In 1974, Niarchos owned 64 ships of $4.4 \mathrm{~m}$ GRT. This not only made him a top shipowner, but also master of an entire business environment, focusing on the tanker market. Shipping, being an international industry, was the victim of many major political events, and Niarchos, born in 1909, was a victim of the same events. Niarchos pursued economies of scale. Niarchos did not come from an Aegean Islands, which were the birthplace of many shipowners. Fifty Greek shipowners came from Chios and Aignouses. While Onassis failed as a father, Niarchos failed as a husband, marrying six wives, five women, and his tankers making the sixth.
\end{abstract}

\section{Keywords}

The Shipping Industry, 1950-2021, Oil Price Elasticity of Demand, Opinions of 16 International Shipowners, The International Tanker Market since 1956, Economies of Scale, The Business Life of Stavros Niarchos, 1940-1996

\section{Introduction}

Shipping is an important service industry, linking the lands of production with the places of consumption, constructing bridges between oceans and between exporting and importing countries. Sometimes the industry grows, and at others 
it is subject to recessions/depressions, following roughly eight-year cycles historically. A manager has to be prepared and educated to manage in a cyclical and volatile industry. It has been an aim in almost all of our papers to educate future managers, because maritime prediction is not possible, but volatility creates great opportunities.

The course of the world fleet, in GRT, for 51 years, is shown in Figure 1.

Table 1 summarizes the relevant developments.

The global financial crisis from the end of 2008 lasted more than 8 years (to 2019), followed by COVID-19 Pandemic (to 2021), completed the decline of the shipping industry. Certain further events have taken place as shown in Table 2.

Ocean-going shipping plays an important role in global sea trade, and is frequently a victim of political actions, including canal closures, local wars and increases in oil prices! The industry has also made its own mistakes, by ordering ships that proved not to be needed. But this is what one expects from an industry where prediction is not possible. Shipowners feel a recession and a depression when their incoming money diminishes.

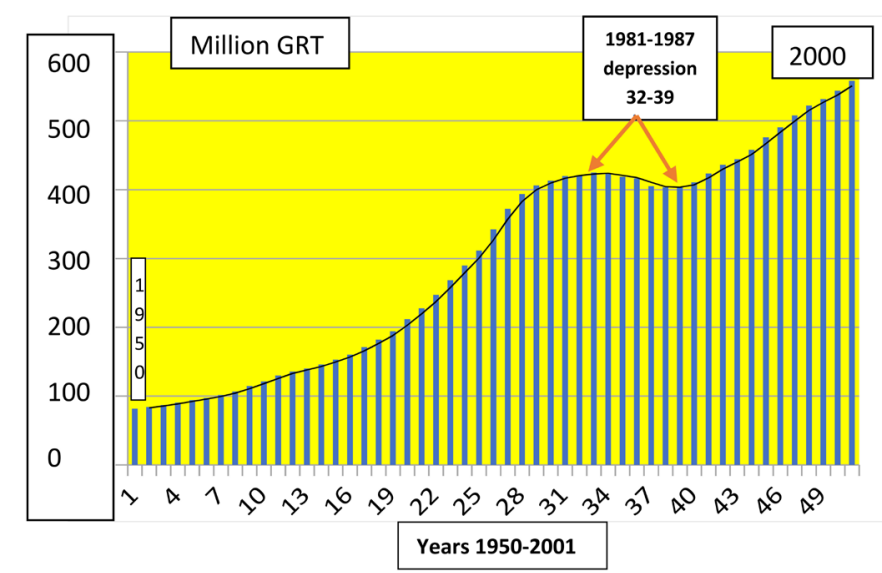

Figure 1. Growth of World fleet, in GRT, 1950-2001. Source: author; data from "OECD Maritime Transport", various years.

Table 1. Developments in world fleet, 1950-2008.

\begin{tabular}{cc}
\hline Year & Change \\
\hline $1950-\left(1^{\text {st }}\right.$ year $)$ & Continuous growth \\
$1969\left(20^{\text {th }}\right.$ year $)$ & $9 \%$ \\
$1975-1977\left(26^{\text {th }}-28^{\text {th }}\right.$ years $)$ & $10 \% ; 9 \%$ \\
$1979\left(30^{\text {th }}\right.$ year $)$ & Tanker depression; multiple oil price rises \\
$1981-1987\left(32^{\text {nd }}-39^{\text {th }}\right.$ years $)$ & Low or negative growth rates \\
dry cargo depression & \\
$1989\left(40^{\text {th }}\right.$ year $)$ & Fleet's growth returned, $1.8 \%$; lower growth rates than before 1975 \\
$1993\left(44^{\text {th }}\right.$ year $)$ & $6 \%$ (good year) \\
$1994-2008$ & Matters improved \\
\hline
\end{tabular}

Source: author; data taken from Figure 1. 
Table 2. Main global events that influenced shipping industry from 1970 to 2021.

\begin{tabular}{ccc}
\hline Year & Event & Remarks \\
\hline $1970-1980$ & A slump of 10 years & \\
$1980-1990$ & A comeback to normal & 1981-1987 dry cargo depression \\
1975 & Fall in demand for oil for the $1^{\text {st }}$ & \\
time in its history & \\
1979 & Oil price rise & From $\$ 11 / \mathrm{b}$ to $\$ 40 / \mathrm{b}$ \\
$1979-1987$ & Tanker crisis & \\
$1979-1983$ & Oil trade fell from & Fall $64.5 \%$ \\
1979 & 1.4b barrels (1979) to 0.9b (1983) & \\
Iraq revolution & 11 years \\
2008 -end to 2019 & Global financial crisis & \\
$2020-2021$ & Pandemic COVID-19 & \\
\hline
\end{tabular}

Source: Data from Stopford (2009) \& author.

\section{Aim and Organization of the Paper}

The aim of this paper is to present the business life of a past pioneer shipowner-manager- and display his strategies to help prospective shipping managers gain some useful lessons and insights. This paper aims to educate interested persons about what they face in the real shipping business, as Niarchos has done.

The paper is organized first in a literature review, followed by four numbered parts. Part I, deals with the important concept of elasticity of demand. Part II deals with the situation prevailing in the international market for tankers, from 1957 to 2008. Part III, addresses the economies of scale and other issues in the shipping sector. Part IV describes Stavros Niarchos' business life, 1909-1996. The paper ends with conclusions.

\section{Literature Review}

The shipping industry is poor at analyzing the strategies of its own managers in either articles or books. The exception is Onassis, who is the subject of about 10 books. This is because Greek shipowners prefer to work in the shadows, unnoticed, so as to avoid envy. Only journalists have published a number of books about the lives of shipowners, mainly based on interviews. They will be used as sources here. The Greek shipping journalist, Mpatis (1999), wrote about 43 people who have played an important role in Greek shipping, of whom 37 were shipowners, between 1957 and 1990.

Stopford (2009: p. 3) also wrote that, "the great shipping boom of 2004 swept the industry from rags to riches in little more than a year, making its fortunate investors some of the wealthiest people in the world. This sort of volatility created superstars, like Niarchos”.

The so called "independents" in oil transport were shipowners of a new generation, descendants of the tramp operators, who had served the liner companies for the previous 100 years, supplemented by a new generation of businessmen 
such as Niarchos, who saw the opportunities in shipping. Niarchos was the stuff of legends and entrepreneurs made a fortune in ship-owning in the last half century (Stopford, 2009).

La Rocco (2012) wrote about 20 international shipowners, of which 2 are Greeks: Nicholas Pappadakis and Angeliki Frangou. The afterword of her book was written by Martin Stopford ${ }^{1}$, and the ex-President of USA Donald Trump found it "powerful"!

Lorange (2020) presented at least 11 shipping companies and concluded that the key-factors are now different than of what used to be, in each one of them, as shown in Graph 1 below.

As shown, in all 14 cases of companies examined by Lorange in 2020, their CEO have played the key-roles. CEO was the driver in revising company's strategy, and he was the key-player in implementing it. As far as the critical innovations were concerned, these could not take place unless the CEO was firmly behind them. In shipping, regulations set by IMO generally drive the major policy changes, the key-shifts in shipping competitive investments or critical innovations. The key shipping markets now have to be well understood to achieve a good timing in the decisions concerning buying ships. As far as IT is concerned for $\mathrm{CEO}$ it must be his/her common theme especially as how large companies have to be run.

Goulielmos (2021a, 2021b) analyzed the business lives of 3 pioneer Greek shipowners: Aristotelis S. Onassis, H. N. Vafias and Angeliki N. Frangou. Angeliki by the way provided two major lessons: 1) To focus on controlling company's costs; she thought it part of her culture, and she managed to keep the costs of her company at $70 \%$ of industry's average, and 2) to realize that, in business, one person cannot do it all; and thus, shipping is a team work.

Table 3 presents the main advice delivered by the 15 international shipowners and financiers interviewed by LaRocco.

McCleery (2013) wrote that once a fund-manager interested in shipping, but unrelated to the industry, saw on his Bloomberg terminal that the BDI-Baltic Dry Cargo Index (daily rates), fell by $97 \%$, to a 25 -year low in just 3 months! In

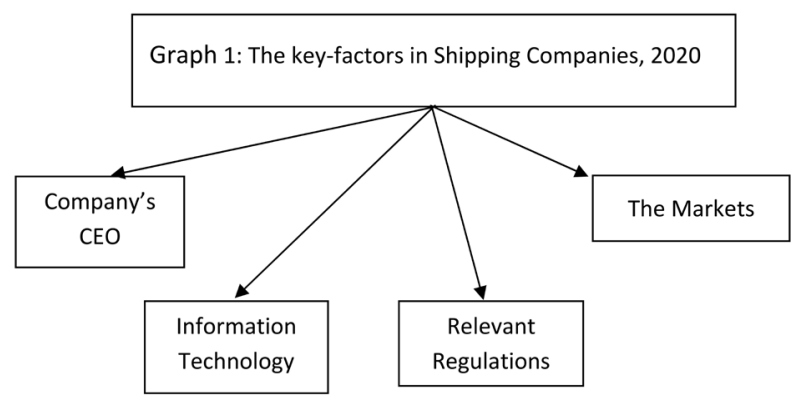

Graph 1. The key-factors in Shipping Companies, 2020. Source: inspired by Lorange (2020).

${ }^{1}$ Author of the "Maritime Economics" book, 2009, which is an encyclopedia and basic textbook for maritime economics. 
Table 3. Main opinions of 15 international shipowners about shipping business, 2012.

\begin{tabular}{|c|c|}
\hline Name & Main points \\
\hline Niels G. Stolt-Nielsen & $\begin{array}{l}\text { When an opportunity crosses your desk, ask: "Is this the } \\
\text { long-term best thing for my company?" }\end{array}$ \\
\hline Philippe Louis-Dreyfus & $\begin{array}{l}\text { A good name goes together with respecting one's commitments; } \\
\text { cycles are faced by common sense; remember what it goes-up, it } \\
\text { may go down in next months or years }\end{array}$ \\
\hline John Fredriksen & $\begin{array}{l}\text { Shipping business is simple: hard work; look at all information; } \\
\text { deal - \& find- fast, good values; go public, think private; back } \\
\text { people by giving them some of the extra money one made; do } \\
\text { deals that can be explained in } 1 / 2 \text { a page; think how much one is } \\
\text { going to lose }\end{array}$ \\
\hline Peter Evensen & A crisis = an opportunity \\
\hline Charles Fabricant & Recognize a changing trend \\
\hline James Tisch & Worry about downside \\
\hline Dagfinn Lunde & Work hard; have alternatives \\
\hline Roberto Giorgi & $\begin{array}{l}\text { You need to move fast; keep things simple; human capital is the } \\
\text { asset }\end{array}$ \\
\hline Nicholas Pappadakis (Greek) & $\begin{array}{l}\text { Decisions affect people - think them } 10 \text { times over; crew's loyalty } \\
\text { is important in ship owning }\end{array}$ \\
\hline Andreas Sohmen-Pao & $\begin{array}{l}\text { Merging \& acquiring are constructive; a company bought can } \\
\text { be in an interesting position if its abilities \& cultures are } \\
\text { complementary with those of the buyer; the resulting entity } \\
\text { can be much stronger; be calm over cycles }\end{array}$ \\
\hline Gerry Wang & $\begin{array}{l}\text { Good credit borrows money; be conservative; have a leverage } \\
\text { below } 60 \% \text {; buy low; look long-term }\end{array}$ \\
\hline Tor Olav Troim & When one has a debt, he/she needs to service it \\
\hline Morten Arntzen & Success comes when preparation meets an opportunity \\
\hline Robert Yuksel Yildirim (Turk) & Money creates money \\
\hline Kristin Holth & Know \& trust management before lend money to it \\
\hline
\end{tabular}

Source: selected from La Rocco (2012), pp. 230-237.

shipping one has to value volatility (Lesson 1). This happened in a time of inflation and deflation, of the dot.com bubble in 2001, the rise and fall of the housing market by 2008 , and the bull-run in agricultural goods, crude oil and gold. The ships were cheaper, their prices dropping 50\% within few months. A Greek shipowner paid $\$ 40 \mathrm{~m}$ for a brand new $6500 \mathrm{TEU}^{2}$ containership, ordered at a price of more than $\$ 100 \mathrm{~m}$ a short time before.

A non-shipping person looks in the cash-flow. A shipping person knows, when it comes to buying ships, that the best deal has the worst cash-flow, and one cannot get a good price and good cash-flow at the same time (Lesson 2). In shipping, the market is the king, and if one's timing is incorrect, one may never make the money he/she perhaps deserves (Lesson 3). Fifty ships can be bought ${ }^{2}$ Containerships are distinguished by their capacity to carry a number of boxes of a standard size within which cargo is transported. The original idea came from the Irish road transporter Malcom McLean in the 1950s. Boxes can be transported by trucks, by trains and by ships and are characterized for this reason "intermodal". 
and sold each week. Both sellers and buyers think they are doing the right thing. But both cannot be right.

In shipping, to gain an advantage over one's competitors ${ }^{3}$, one has to: 1) pay less for ships, 2) pay less for operation, and 3) pay less for capital (Lesson 4). A "shipowner-to-be" must realize that he/she can buy the greater part of a ship with other people's money, a practice first employed by Onassis (Goulielmos, 2021a, 2021b). The Financial Times once noted: "The unexpected surge in the demand for industrial goods that resulted from China joining the WTO -world trade organization, in 2002, resulted in the world being caught short on ships".

Low-valued goods have no alternative way to be transported in bulk, except by using ships, and the tentative imbalance in the supply of ships and the demand for them, may send shippers searching for ships (Lesson 5) (Figure 3). The demand for ships and the supply of them determine the reward paid to ships (the freight rate), and her value (price). Given that there are about 33,000 shipowners globally owning $100,000^{4}$ ships, the situation approximates to pure competition in supplying ships for sale or chartering. Their price can settle anywhere on the Cartesian diagram of supply and demand, either very high or at rock bottom.

The Economist once wrote that, due to economies of scale, even a tripling of charter rates would not add much to the price of goods transported. This can be explained by the fact that the goods transported by ships are low-valued and their freight rate is a small percentage of their price, perhaps $10 \%$ on average. In fact, the liner cartels, called "conferences", determined their freight rates so that they did not increase CIF prices ${ }^{5}$ (prices at the destination) beyond a level allowed by the elasticity of demand. Otherwise, they might have priced- exports -out of the market, and thus out of any transport. Shipowners do not want this.

In 1975, OPEC, by increasing the price of oil, dramatically reduced the demand for oil, as shown in Figure 8. When shipowners have plenty of cash, they place orders (Lesson 6). Sometimes, however, the new ships are not needed. The bankruptcy of Lehman Brothers damaged sea trade, because it led to the collapse of inter-bank letters of credit, which are the lubricant of international ocean ${ }^{3} \mathrm{~A}$ ship owner who has to move their own goods may charter out their own ships and then charter-in other ships cheaper.

${ }^{4}$ At the end of February 2021, Clarkson's Research announced that world fleet reached 100,000 ships. Of those, $25 \%$ were eco-friendly and $20 \%$ are fitted with a scrubber avoiding the air pollution.

${ }^{5}$ The CIF price equals the FOB price (free on board) increased by insurance and transport cost. Assume that oil is priced $\$ 100 / \mathrm{b}$ at the departure port (FOB), and sea transport cost is $\$ 10 / \mathrm{b}$ and insurance cost $\$ 5 / \mathrm{b}$, so, $\mathrm{CIF}_{1}$ is $\$ 115$. Suppose that the freight rate now rises to $\$ 40, \mathrm{CIF}_{2}$ will increase to $\$ 145$. Suppose next that the demand for oil at destination falls $30 \%$, say from $13,000 \mathrm{~b} /$ day to 9100 , due to this increase in price. The arc Elasticity of demand is: $\mathrm{Q}_{1}-\mathrm{Q}_{2} / \mathrm{Q}_{1}+\mathrm{Q}_{2}{ }^{*} \mathrm{P}_{1}+\mathrm{P}_{2} / \mathrm{P}_{1}-\mathrm{P}_{2}\{1\}$ and so: $\mathrm{e}=1.53$, which is greater than 1 . This elastic demand does not suit shipowners, because the supposed increase in price by $\$ 40 / \mathrm{b}$, reduced the quantity demanded (and transported) by $3900 \mathrm{~b} /$ day. Less work for the ships. As a result, the shipowners arranged for oil to pay a freight rate of only $\$ 15$, instead of $\$ 40$. The quantity demanded in this case fell from $13,000 \mathrm{~b} /$ day to only 12,900 , giving an $\mathrm{e}=0.18$, which is less than 1 , and inelastic. As a result, the quantity transported fell by $100 \mathrm{~b} /$ day instead of 3900 , and the loss fell from $\$ 39,000$ per day to $\$ 1500$ per day. A great improvement. The conclusion from the above exercise is that first calculate the elasticity of demand of the good to be transported, then determine the freight rate such as not to cut it from consumption at destination meaning also exclusion from transport! 
shipping.

It was reported in Marine Money that the shipowner Jim Tische ${ }^{6}$ bought a fleet of new ships at scrap prices, and ... parked them until the market recovered and thus made a fortune by selling them. The lesson from this is that one should buy ships at rock bottom prices, and if market does not recover, to lay- them -up until it does. In fact, it is possible to calculate the benefit of lower prices in terms of the cost and the time of laying up ships and freight rates and values.

All great shipowners did focus on issues like where to build ships and why, and where to borrow money from and how (lesson 7), like Onassis and Niarchos. German banks e.g., were exposed to the sector of containerships, and to US sub-prime mortgages, thus having an urgent need for cash. From Hamburg, 35\% of the global containership fleet was controlled, due to a favorable tax treatment and low-cost loans. At that time (2009) 50\% of shipping loans were in default, according to financial news.

There was a case where a ship valued at $\$ 56 \mathrm{~m}$ in 2007, bought with a bank loan of $\$ 43 \mathrm{~m}$ or $77 \%$, was valued in 2009 at less than $\$ 25 \mathrm{~m}$. The borrower had to pay the remaining $\$ 40 \mathrm{~m}$. If the bank foreclosed on the loan, and took title to the ship, it would have to auction the ship, pay-out any unpaid creditors (for example for fuel, which might be $\$ 3 \mathrm{~m}$ bill), suffering at the end a loss of about $\$ 18 \mathrm{~m}$. The lending bank decided instead, in a such situation, to give the ship to other ship owning clients, lending them the required working capital ${ }^{7}$ until the market recovers. In this way the bank reduced its losses. Even if the shipping crisis would last 10 years, the loss of the bank would only be $\$ 13.3 \mathrm{~m}^{8}$ which is less than $\$ 18$ m otherwise.

Summarizing, important maritime lessons can be taken from the 17 shipping managers interviewed by the shipping journalist: McCleery in 2012. Seven basic shipping lessons were important from the period 2009 to 2013. Though maritime history may not repeat itself, past lessons have to be remembered and compared with present or future conditions, so that managers to be prepared (Goulielmos, 2009).

\section{Part I: The Concept of the Elasticity of Demand}

An economic law applied, when the main oil producers more than tripled its price, in 1979. The law states that when the price of a commodity increases, the quantity demanded is reduced, given its elasticity of demand. Traditional economists did not expect the quantity of oil demanded to fall, as they assumed it to be highly inelastic. They were right apart from 1975. The price elasticity of demand is a very important tool for shipping, because, when freight rate increases, and results in a rise in the CIF price, it is possible to calculate the drop in demand, and also the drop in revenue for the shipowner (Revenue $=$ Freight rate * Quantity transported \{2\}) (Besanko et al., 2013: pp. 9-10).

${ }^{6} \mathrm{CEO}$ of Loews Corporation-a New York City based investor.

${ }^{7}$ This covered the first 3 chapters of McCleery's book.

${ }^{8} \mathrm{On}$ the assumption that this vessel will cost $\$ 2.55 \mathrm{~m}$ per year in expenses ( $\$ 7000 /$ day) and she will earn $\$ 1.22 \mathrm{~m}$ per annum ( $\$ 3500 /$ day) in a crisis, it will take 13.5 years to lose $\$ 18 \mathrm{~m}$. 
The elasticity of demand is the percentage change in the quantity demanded (dependent variable), divided by the percentage change in price, at the limit: $\mathrm{e}=$ $\mathrm{dq} / \mathrm{q}: \mathrm{dp} / \mathrm{p}\{3\}$, where $\mathrm{q}$ is the quantity demanded and $\mathrm{p}$ the price prevailing (Henderson \& Quandt, 1958: p. 168). The elasticity of demand between two points is a more convenient tool, (called "arc e"), shown in Graph 2. It is defined as: $\mathrm{e}=\mathrm{q} 1-\mathrm{q} 2 / \mathrm{q} 1+\mathrm{q} 2$ multiplied by $\mathrm{p} 1+\mathrm{p} 2 / \mathrm{p} 1-\mathrm{p} 2\{4\}$ (Bilas, 1967: pp. 15-23).

The demand for oil, as shown above, and also in Table 2, fell by approximately $64 \%$ (from 1.4 billion barrels to 0.9 billion) and its price approximately quadrupled, from $\$ 11 / \mathrm{ba}$. to $\$ 40 / \mathrm{ba}$., over a period of 4 years (1979-1983). The total revenue of producers increased thus from $\$ 15.4 \mathrm{~b}$ to $\$ 36 \mathrm{~b}$, despite the substantial increase in price, because $\mathrm{e}=-0.04$, which is less than 1 .

The demand for oil fell now to almost $90 \mathrm{~m}$ barrels/day in 2020, or by $10 \mathrm{~m}$ barrels/day, due to the pandemic. In 1990, the oil trade was $32 \mathrm{~m}$ barrels/day (Figure 7). The global economy is still dependent on oil, despite repeated increases in oil prices, because demand almost tripled during the last 30 years!

\section{Part II: The International Market for Tankers, 1957-2008}

Before presenting the strategies of Stavros Niarchos, we show the conditions prevailing in his main market, the tankers. Figure 2 presents the situation between 1957 and 2008.

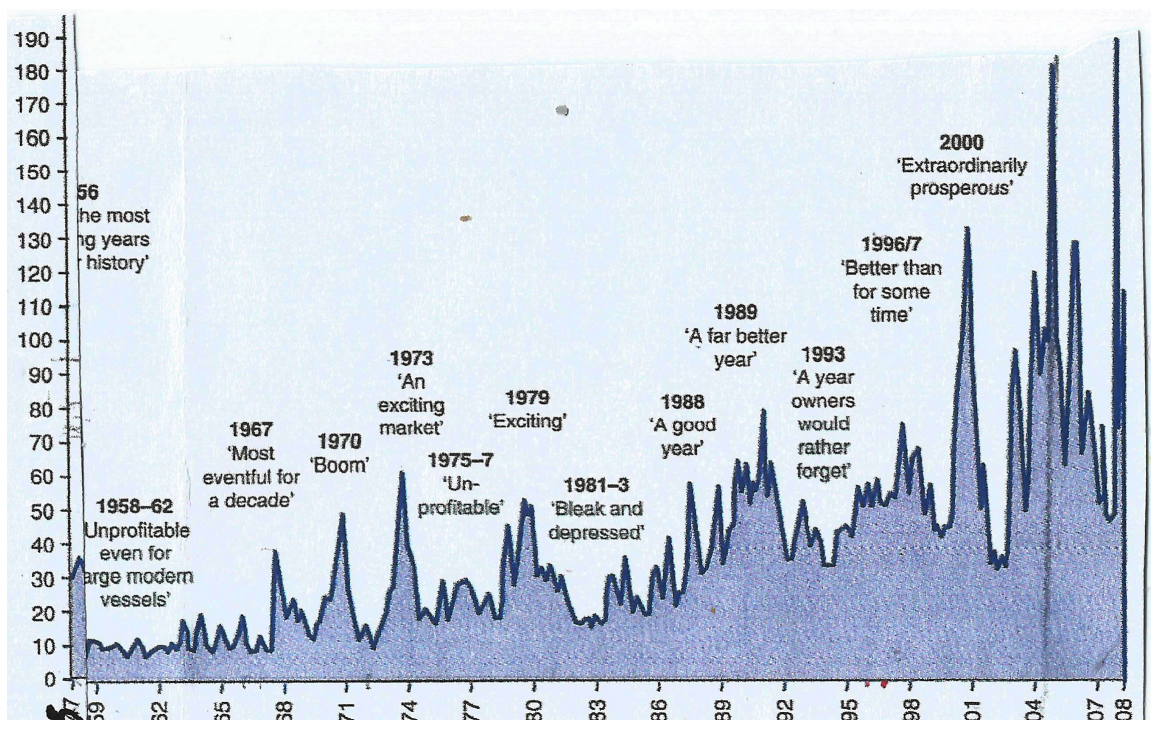

Figure 2. The Tanker market, 1957-2008. Source: Stopford (2009); modified; freight rates expressed in units of the "Worldscale" index".

'This is the short name of "Worldscale tanker nominal freight scale", created in 1969 to provide an independent unit of measurement of tanker rates. Market levels of freight rates are expressed as a percentage of "scale" rates. They assume a nominal tanker function on round voyages between designated ports. The calculated schedule rate is equal to different US\$/ton equivalent for each different route combination, which is the "Worldscale" 100 /flat rate, meaning 100 points of $100 \%$ of the published rate. For example, W60 means $60 \%$ of the published flat rate. The scale is sensitive to bunker prices and port costs. In 1989 the "New Worldscale" appeared with a standard vessel of 75,000 tons and a daily hire of $\$ 12,000$ to be used as a representative situation. For further details see: Kavussanos \& Visvikis (2006). 


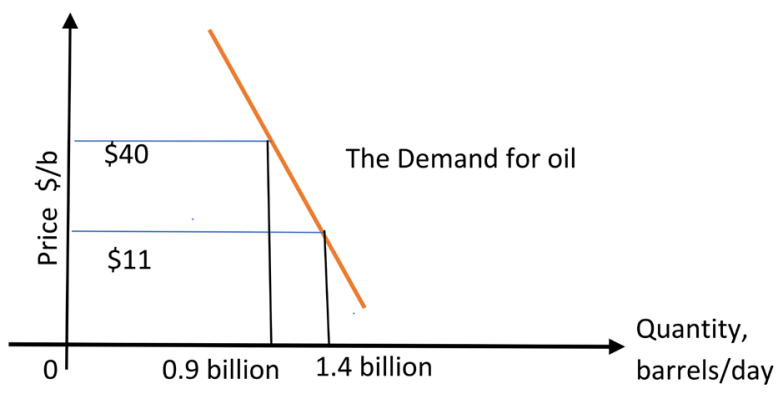

Graph 2. The price elasticity of demand for Oil, 1979-1983 (arc). Source: author.

The main findings are summarized in Table 4.

As shown in Figure 3, $140 \mathrm{~m}$ dwt was the largest gap between tanker demand and supply, in 1983, where supply exceeded demand for the whole period, from 1980 to 1988. The gap started from $65 \mathrm{~m}$ dwt in 1980 and fell to $40 \mathrm{~m}$ in 1988.

Behind the above developments, certain events were taking place (Table 5).

In the shipping industry, a recession or a depression has specific repercussions. They lead to either lay-up of ships or to their scrapping. The lay-up of tankers, for 1983-1990, is illustrated in Figure 4.

As shown, 1984 was a crucial year, because $75 \mathrm{~m}$ dwt tankers were laid-up. Tankers used for storage varied from $10 \mathrm{~m}$ to $20 \mathrm{~m}$ dwt. This means that $95 \mathrm{~m}$ dwt of tankers were inactive due to lack of demand. Figure 5 shows the same situation for 1980-1989 presenting the tanker scrapping/delivery relationship. The global fleet of tankers will grow if a greater tonnage is on order (supply), so that deliveries exceed scrapping.

As shown, scrapping of tankers surpassed deliveries, from 1980 to 1987 inclusive. Scrapping reached a maximum of $27 \mathrm{~m}$ dwt in 1985. Intense scrapping can be seen from 1982 to 1985 with over $18 \mathrm{~m}$ dwt per year and a total of approximately $90 \mathrm{~m} \mathrm{dwt}$ for the whole period. Figure $5 \mathrm{did}$ not indicate the age or the size of the scrapped vessels, but they were very young and very large. There were two factors in force: 1) the higher oil prices (Figure 6) and 2) the fall in world oil trade (Figure 7). This is the worst combination for shipping whenever it happens.

As shown, the price of oil rose to $\$ 30$ - $\$ 37 /$ barrel (spot Brent) from 1982 to 1986 and to $\$ 20$ by January 1990. In January 2017, it was about $\$ 55$ and in January $2021, \$ 52$. This resulted in a fall of oil sea trade from $36 \mathrm{~m}$ barrels per day in 1980 to $22 \mathrm{~m}$ in 1983 and $23 \mathrm{~m}$ in 1987 (Figure 7). Then the situation improved, reaching about $32.5 \mathrm{~m}$ barrels per day, and $90 \mathrm{~m}$ by 2021 .

The course of total shipping demand over 1970-1989 is shown in Figure 8.

As shown, the sea oil trade (demand) was the victim of the depression/energy crises of that time (1974-5; 1979-1989). The drop in oil sea trade from 1979 to 1985 was dramatic, losing 45 units in 6 years.

\section{Part III: Economies of Scale and Other Issues in the Shipping Sector}

The issues that can be raised related to shipping management are: 1) a thorough 
knowledge of market conditions, in order to evaluate the past, but also the future, actions of top-management, 2) the inability of management to change a competitive market into one that favors his/her company, 3) the responsibility for managers for achieving lower profits than his/her competitors, when the conditions are the same for everybody, 4) the responsibility for managers achieving lower costs than his/her competitors, when the conditions are the same for all, and 5) the responsibility for managers for achieving economies of scale, when there is the appropriate demand. We deal first with the last issue.

Table 4. The tanker years, 1956-2008.

\begin{tabular}{cc}
\hline Year & Situation \\
1956 & Most interesting \\
$1958-1962$ & Unprofitable (5 years) \\
1967 & Rates moved-up \\
1970 & Boom \\
1973 & Very good \\
$1975-1977$ & Not enough profit for 3 years \\
1979 & Exciting \\
$1981-1983$ & Bad (3 years) \\
1988 & Good \\
$1989-1991$ & Good \\
$1992-1993$ & Really Bad (2 years) \\
$1996-1997$ & Better \\
1998 & Good \\
$2000-2008$ & Extremely good (8 years)
\end{tabular}

Source: Figure 2.

Table 5. Main maritime events, 1957-1990.

\begin{tabular}{cc}
\hline Event & Year \\
\hline Suez Canal re-opened (after a short closure) & April 1957 \\
Suez Canal re-closed ${ }^{10}$ & May, 1967 \\
An oil crisis took place & October 1973 \\
Suez Canal re-opened (i.e., a long-term closure of 8 years). & June 1975 \\
Iranian revolution & 1979 \\
Iran-Iraq war & 1982 \\
Iraq invades Kuwait & 1990 \\
1957-1990 & Turbulence (Goulielmos, 2018) \\
\hline
\end{tabular}

Source: author.

${ }^{10}$ Closure of the Suez Canal meant that ships' distances became suddenly longer; so, a lack of ships is created pushing up freight rates. Ships had to travel round Africa to reach Persian Gulf. Later ships were made larger to face the longer distances. This happened when the Canal closed for a long time (1967-1975). Small ships are penalized by port expenses, when they frequently visit a port. Larger ships divide all expenses including port ones in a greater number of tons, so there are economies of scale. The longer the distance, the larger the ship should be. 


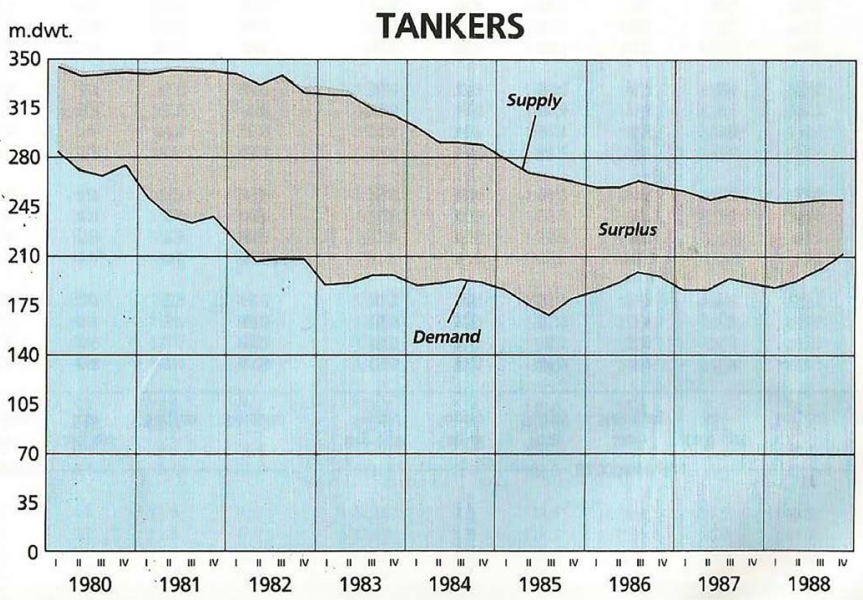

Figure 3. Supply and demand relationship and the gap between the two, 1980-1988. Source: Lloyd's Shipping Economist, 1989.

TANKERS IN LAY-UP AND OIL STORAGE

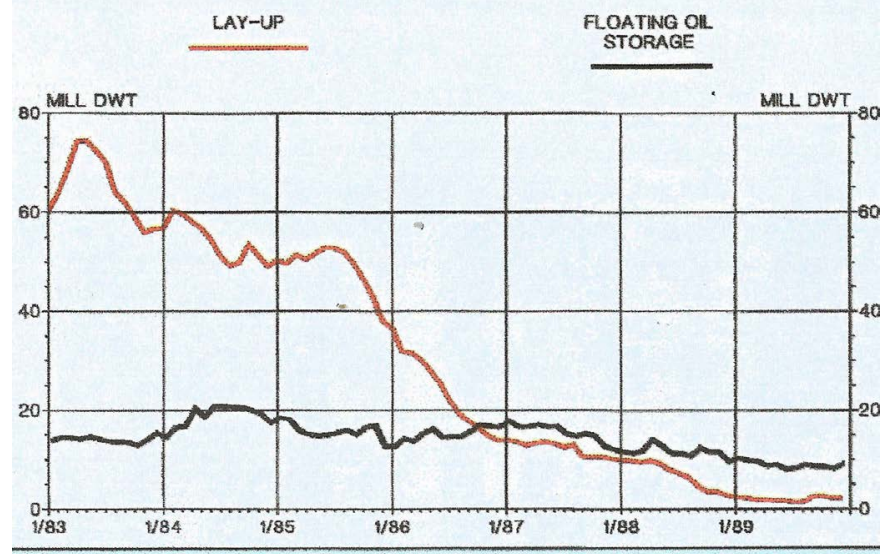

Figure 4. Tankers in lay-up and storage, 1/1983-1/1990. Source: The Platou report, modified.

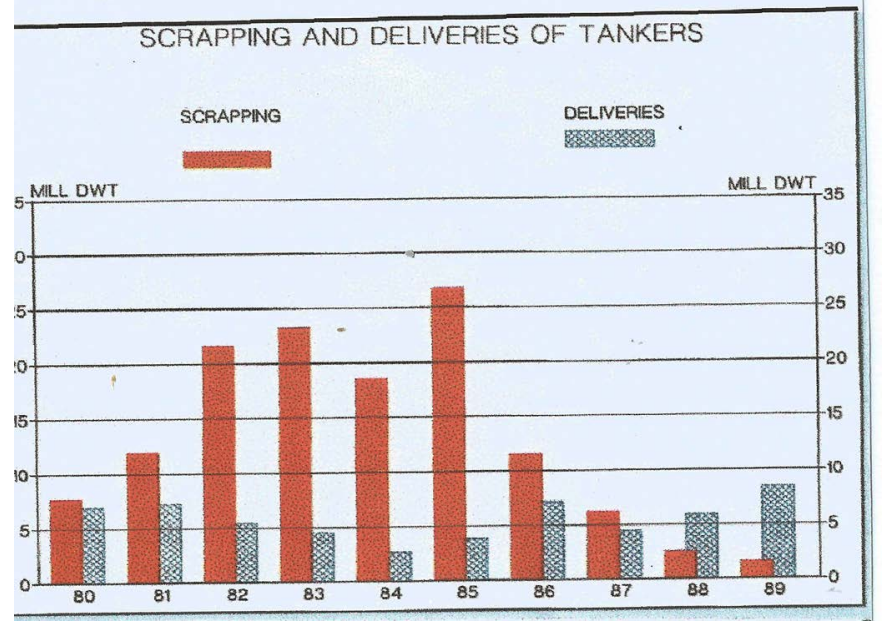

Figure 5. Scrapping and deliveries of tankers, 1980-1989. Source: The Platou report, modified. 


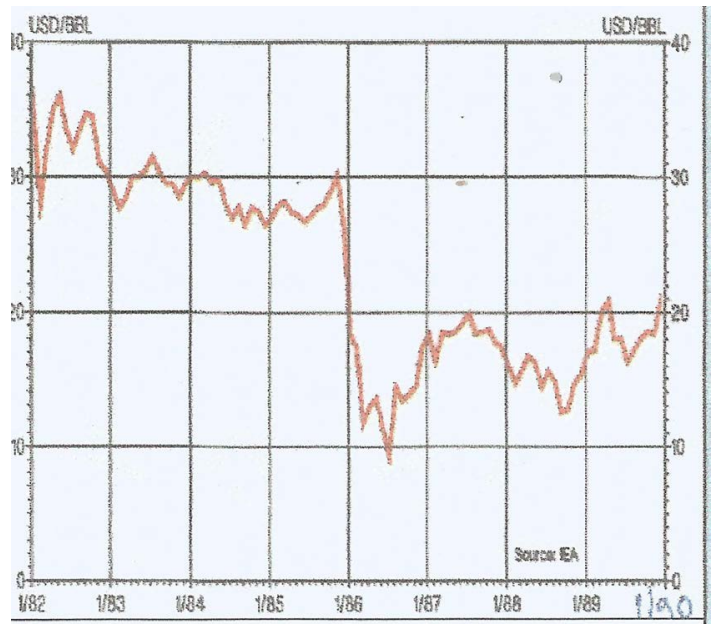

Figure 6. Crude oil Price (Brent spot), 1/1982-1/1990, Source: IEA.

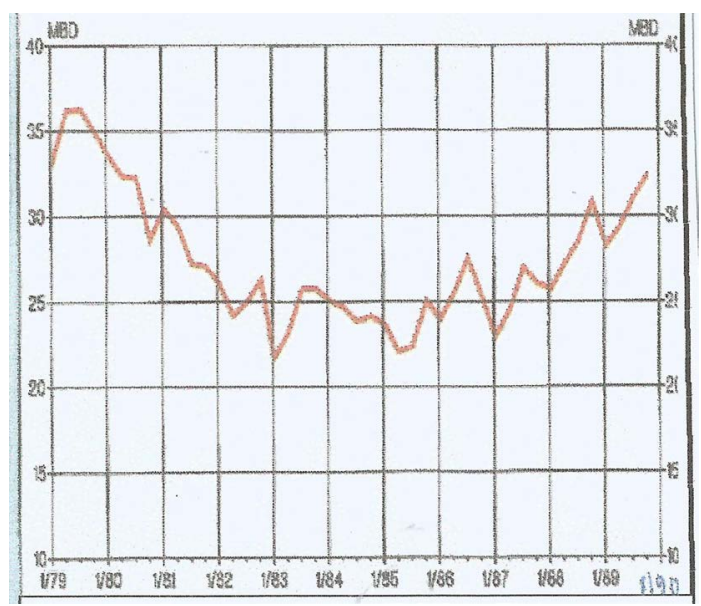

Figure 7. World Oil Trade (quarterly), 1/1979-1/1990, Source: The Platou report.

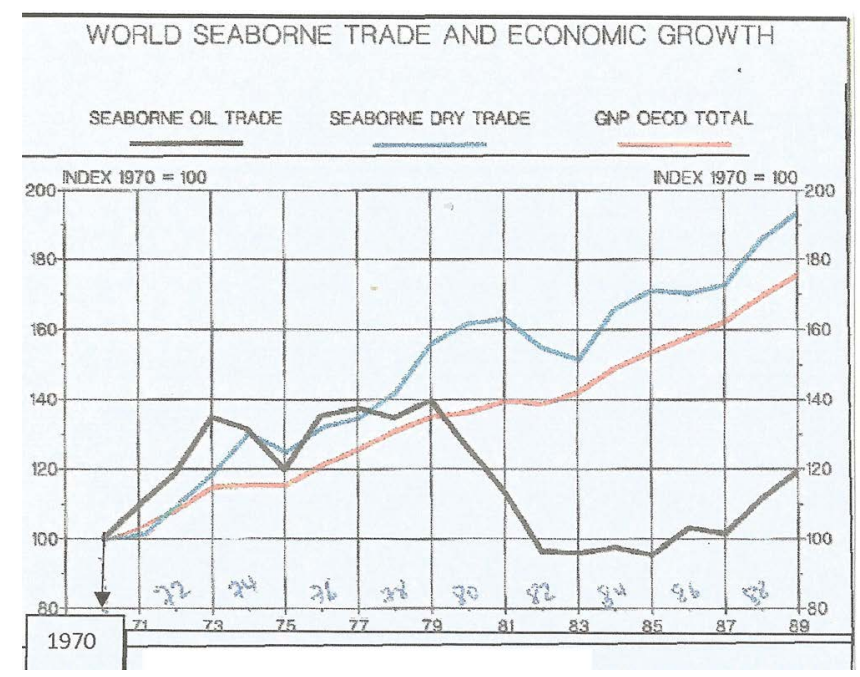

Figure 8. The Global seaborne trade, 1970-1989, for oil and dry Trade and growth in GNP in OECD countries. Source: The Platou report, modified. 
As shown in Figure 9, Figure 10, the average size of the Greek-owned fleet increased, especially between 1962 and 1974. The average size of the fleet in GRT started from 6855 in 1962 and reached 11,154 in 1975 and 20,334 in 1991.

From 1989 to 1994, the average size of vessels (economies of scale) increased further, and thereafter remained stagnant till 1999 (5 years). From 1999 and till 2016 the average size increased continuously (in dwt) from about 34,200 to about 78,350 dwt. The size increases, when the fleet increases, confirming that the strategy of Greek shipowners was to get rid of smaller ships and buy larger

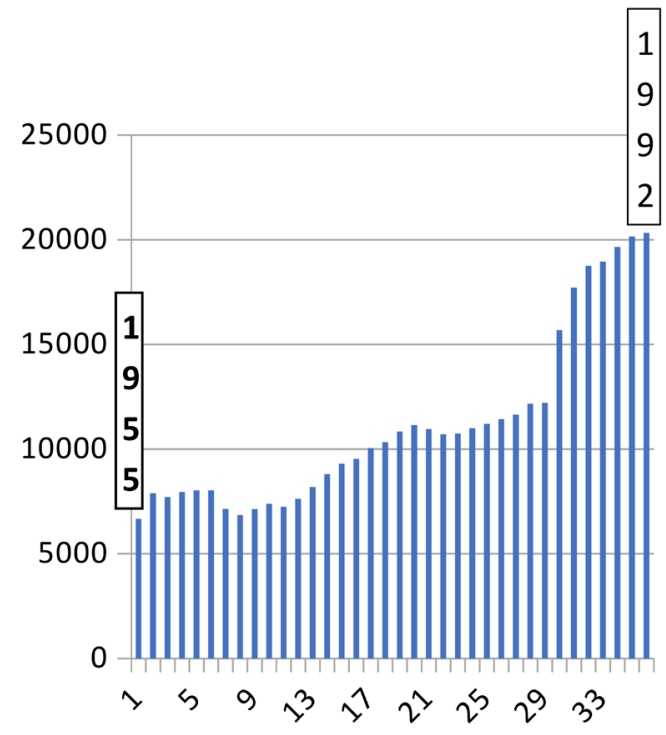

Figure 9. Average size of Greek-owned fleet, 1955-1992, in GRT. Source: author.

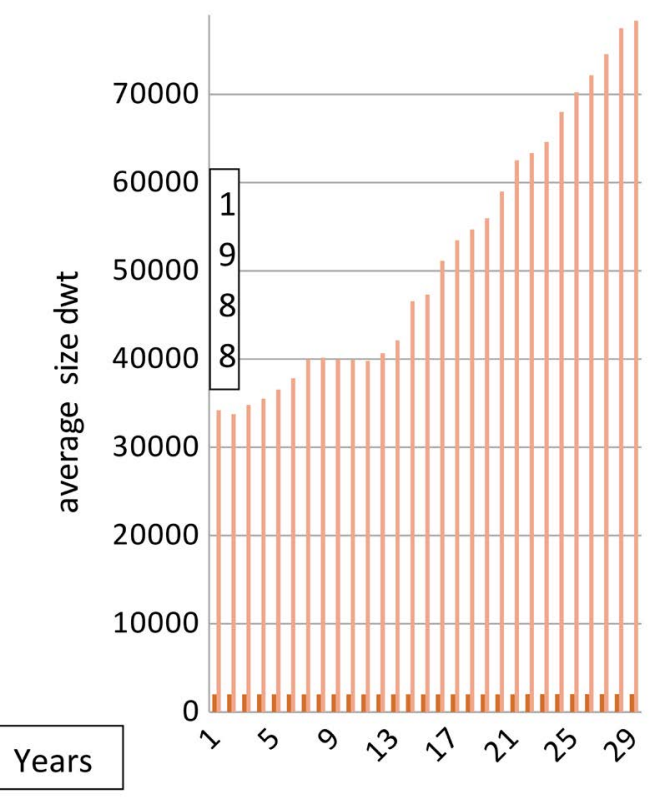

Figure 10. Average size of the Greek controlled fleet, 1988-2016, in dwt. Source: author. 
ones to gain economies of scale (Goulielmos, 2020). This happens when there is a depression, and prices are at rock bottom ... Crises create opportunities, as shown by the global financial crisis of 2008 and the pandemic of 2020/1. In 2002, the largest section of the Greek-owned fleet-34\%-was between 20,001 and 40,000 GRT, making up a total of roughly $33 \mathrm{~m}$. The very large ships over 80,001 were about $23 \mathrm{~m}$ or $23.5 \%$. Finally, the 40,001 and 80,000 sizes covered $26 \%$ or $25.2 \mathrm{~m}$ GRT. The total was $96.5 \mathrm{~m} \mathrm{GRT}^{11}$.

\section{Part IV: The Stavros Niarchos (1909-1996) ${ }^{12}$-Case Study}

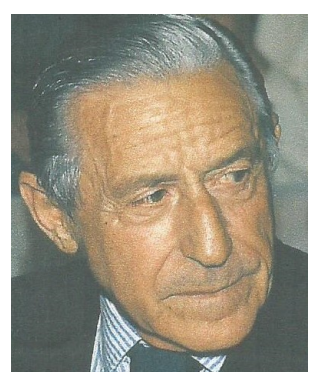

Niarchos (his photo from Frangoulis) was born in 1909 in Sparti (Peloponnesus). He was 9 years younger than Onassis ${ }^{13}$. He was first employed in the flour mill company owned by his mother's brothers, the Kumantaros (in 1930; aged 21). He was also a law student at the University of Athens. He suggested to his uncles that it would be more profitable to buy vessels to transport company's flour and grain, at that time from Russia and Argentina, instead of using other people's vessels. He then took over the sea transport department of the company.

\subsection{Niarchos as a Shipowner-1940 (Aged 31)}

In mid-September 1939, Niarchos terminated his employment at the flour mill, and went to London. In 1940, he bought his first ship, called "Maleas", which was an old small dry cargo ship. He bought it with a loan. This was typical of Greeks at that time, who bought small, old and cheap vessels. Niarchos' vessel "Maleas" sunk during the Second World War.

Niarchos was lucky, however, in his bad luck, as he received war compensation $^{14}$ and a new loan. With this he was able to obtain another four ships ${ }^{15}$. These vessels flew the Panama's flag. The allies, however, requisitioned them all. During the Second World War Niarchos returned to Greece, and served in the Greek ${ }^{11}$ The figure is lower than the one provided by Lloyd's Register of Shipping, which in March 2002 recorded $98.2 \mathrm{~m}$.

${ }^{12}$ Based on the book written by Mr. Frangoulis G K, (2001), "Stavros Niarchos: my experience working with him”, Fereniki editions. Also: Theotokas \& Harlaftis (2009) \& Kapsis (2005).

${ }^{13}$ Certain publications mention Onassis as born in 1900. When he was in Argentina, he increased his age to obtain a work permit, while he reduced it to avoid Turkish exile (Goulielmos, 2021a, 2021b).

${ }^{14}$ From other sources (Kapsis, 2005), Niarchos had 2 vessels for which he received $\$ 1 \mathrm{~m}$ for a war compensation.

${ }^{15}$ Two of them were named after: Captain J Mataragas and Captain J Papazoglou; these ships were lost during the Second World War. 
Army. In 1945, he transferred his company to New York, as many Greek shipowners did. The USA environment helped Niarchos, because he saw there the sharp increase in oil trade at its birth. Niarchos entered into the class of traditional shipowners by marrying the elder daughter of Stavros Livanos, Evgenia.

\subsection{Niarchos and the Liberty Ships-1946}

In 1946, Niarchos bought 6 Liberty-T2 tanker ships together with Emmanuil. The tankers were of 12,000 dwt each, or 16,000 dwt, depending on cargo stowage factor. Greece received from the USA (lend-lease) seven tankers in all, of which Niarchos bought six. Niarchos paid $\$ 2 \mathrm{~m}$ for each. He also bought one Liberty ship for himself and one jointly with the Kumantaros.

\subsection{Niarchos as a Further Shipowner, 1947-2000-Economies of Scale (Aged 38)}

The fleet of Niarchos in 1947 consisted of only one vessel of 14,480 GRT. By 1957, after ten years, Niarchos owned $2 \mathrm{~m} \mathrm{dwt}, 41$ tankers of $1 \mathrm{~m}$ dwt and 20 dry cargo of $1 \mathrm{~m}$ dwt. Niarchos realized the importance of economies of scale. His vessel "World Harmony" was of 25,000 dwt, and his "Al Malik Saud El Laval" was 45,000 dwt.

In 1957 (Niarchos, aged 48) a shipping depression occurred and Niarchos reduced his company's costs by $20 \%$, and certain of his ships were laid-up at "Elefsina Bay", a Greek port near Piraeus used as a lay-up port/area. By 1958 (aged 49), the Niarchos' fleet had grown to 64 ships of 1,023,255 GRT (of which eight were dry cargoes).

Niarchos' fleet developed was as shown in Table 6 (1947-2000).

In 1976, Niarchos' fleet peaked at $3.7 \mathrm{~m}$ dwt and in 1974 reached $4.4 \mathrm{~m} \mathrm{GRT}$ (Table 6, Figure 11).

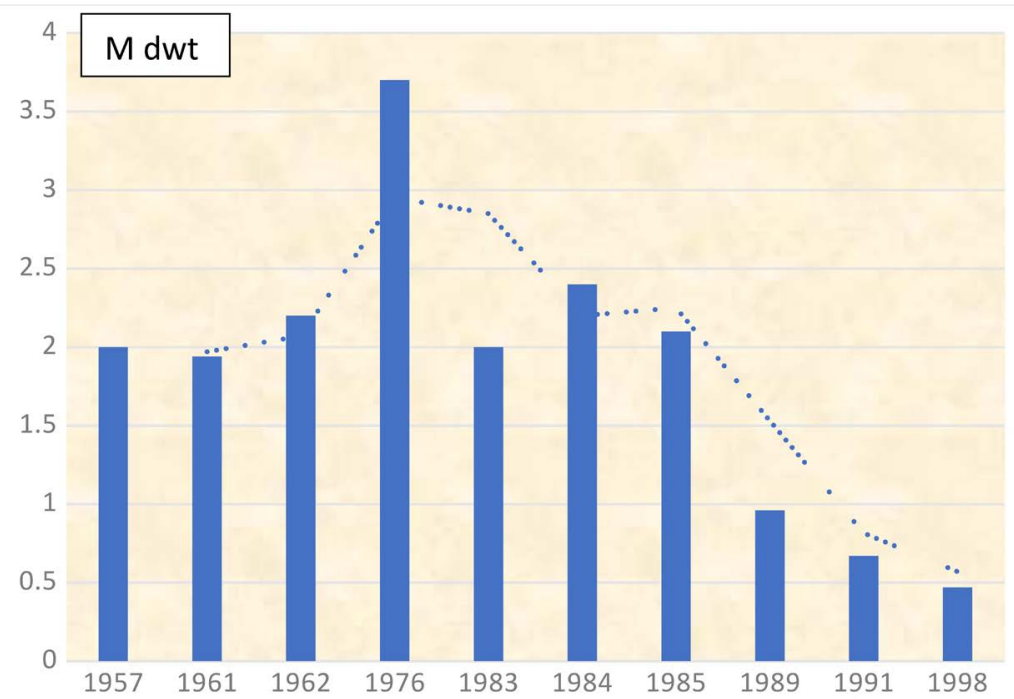

Figure 11. Niarchos' fleet growth, 1957-1998, various years. Source: Data from Table 4 (in dwt). 
Table 6. Niarchos fleet development, 1947-2000, various years.

\begin{tabular}{|c|c|c|c|}
\hline Year & $\mathrm{Nu}$ & sGRT, or DWT & Remarks \\
\hline 1947 & 1 & 14,480 GRT & \\
\hline 1957 & 61 & $2,000,000$ & 41 tankers $1 \mathrm{~m} \mathrm{dwt} ; 20$ dry cargoes $1 \mathrm{~m} \mathrm{dt}$ \\
\hline 1958 & 64 & $1,003,000 \mathrm{GRT}$ & 56 tankers; new-buildings 39 (61\%) \\
\hline 1959 & 64 & $1,175,000 \mathrm{GRT}$ & $\begin{array}{l}\text { Tankers over } 6000 \text { dwt. } 86 \%<10 \text { years of age; } 8^{\text {th }} \\
\text { global position for tankers over } 6000 \text { GRT, of } 0-5 \text { years } \\
\text { of age }=59 \% \text {. }\end{array}$ \\
\hline 1961 & 72 & $1,942,000$ & \\
\hline 1962 & 74 & $2,186,834$ & $2^{\text {nd }}$ in the world after "Ludwing" \\
\hline 1965 & 70 & $1,400,000 \mathrm{GRT}$ & 55 tankers; 15 dry cargo \\
\hline 1973 & 62 & $4,326,418 \mathrm{GRT}$ & 46 tankers $(82 \%)$ \\
\hline 1974 & 64 & $4,403,327$ GRT & $\begin{array}{l}2 \text { OBOs } 224,677 \text { GRT }(81 \%) ; 47 \text { tankers (14\%); } 15 \text { dry } \\
\text { cargoes }(5 \%)\end{array}$ \\
\hline 1975 & 46 & $1,786,000 \mathrm{GRT}$ & 31 tankers; 15 dry cargoes \\
\hline 1976 & 51 & $3,666,227$ & 5 VLCCs (April) \\
\hline 1981 & & $1,605,000 \mathrm{GRT}$ & A crisis started in dry cargoes \\
\hline 1983 & 19 & $2,046,145$ & $\begin{array}{l}\text { Since } 1980 \text { the fleet had a decadence; also } 26 \% \text { of dwt } \\
\text { tonnage was old }\end{array}$ \\
\hline 1984 & 33 & $2,400,000$ & \\
\hline 1985 & 32 & $2,132,995$ & $\begin{array}{l}\text { From other source: } 31 \text { ships of } 1.9 \text { m GRT; } 9 \text { tankers, } \\
2 \text { combos, } 20 \text { bulk carriers }\end{array}$ \\
\hline 1989 & 26 & 958,602 & \\
\hline 1991 & 24 & 673,562 & A new generation took over \\
\hline 1995 & 18 & & Niarchos passed away in 1996 \\
\hline 1998 & 13 & 467,573 & \\
\hline 2000 & 11 & & $\begin{array}{l}4 \text { tankers; } 2 \text { bulk carriers \& } 5 \text { product carriers; company } \\
\text { turned into a fleet renewal \& growth, by ordering } 1 \\
\text { ULCC and } 2 \text { Suezmax tankers (in Daewoo). }\end{array}$ \\
\hline
\end{tabular}

Source: author; from Frangoulis (2001); Kapsis (2005); Zannetos (1966); Naftiliaki journal; Skolarikos.

\subsection{The Vertical Integration Principle (1957): Niarchos' Philosophy (Aged 48)}

Niarchos was the only shipowner who realized first the importance of vertical integration, an idea he first applied to the flour mill company where he worked for. This idea was applied by Japan, which had no iron ore or oil. This idea led Niarchos to establish: a steel-mill, producing the raw material (steel) for his ships, a shipyard: for building them, and a fleet: that he owned and managed.

Niarchos took part in several Greek projects from 1945 to 1975. In 1957, he established the "Hellenic Shipyards" in Greece (at Skaramagas, near Piraeus) over 292 acres at a cost of about $\$ 9 \mathrm{~m}$. The ship construction there was initially mainly tween-deckers, small bulk carriers and tankers, and the shipyard employed about 6000 workers. In 1958, Niarchos reconstructed the shipyard, and 
placed a Dutch administration there. Later this administration was replaced by a Greek one. The director was then the Greek, Mr. Dracopoulos, husband of Niarchos' sister, since 1949.

By February 2021 the shipyard was bankrupt and had been up for sale since 2011. It now extended to 650 acres, and employed only 780 workers. The state asked for a price of $€ \sim 70 \mathrm{~m}$, substantially above the value of the land, which was estimated at $€ 55 \mathrm{~m}$. There are also $€ 10 \mathrm{~m}$ realized costs, while the average cost per employee is about $€ 1.67 /$ month. The sale effort will continue at a lower minimum price, inviting new buyers during 2021.

Niarchos became a partner and administrator of the "Aspropyrgos Refineries" in 1957/8, together with Mobil, where his involvement ended in 1976/7. He was also involved as a major shareholder in the "Greek Alumina Industry" in Greece, from 1960 to 1966, run by French company Pechiney.

The Niarchos shipyard project was ill-fated, suffering from bad timing, because an economic cycle took a downturn. There was no state, or other, finance, for ship construction at that time in Greece, and Greek shipowners doubted the ability of Greek workers to build ships. They may not have wanted to assist a competitor to become wealthier by building ships in his shipyard.

The yard eventually became a repair yard, and it repaired about $70 \mathrm{~m} \mathrm{dwt}$ ships in ten years. Also, the yard was affected by the long Suez Canal closure, and by the opposition of the shipyard's labor union, after 1981, under the socialist Government of PASOK. The yard more or less restricted its production to the SD14- ship type- in its first decade ${ }^{16}$. Global shipyards like this also felt the competition of Japanese shipyards. Niarchos failed to protect his shipyard from the antagonism of other Greek shipowners at the time of yard's establishment, and he failed to create a monopoly there.

Another shipowner and banker, Mr. S Andreadis, an influential man, and Professor took the opportunity to get a permit from the Greek state to establish another shipyard nearby, at "Elefsina Bay" in 1969, just 12 years after Niarchos has been privileged, and that privilege was due to expire in 1974, and not in 1969. Anyway, Niarchos concentrated the opprobrium of almost all other Greek shipowners. Niarchos was also a supporter of the Greek Royal Family.

Finally, Greek state "helped" Niarchos, as orders were placed for 25 plus dry cargoes to be built in Niarchos' shipyard of the SD14 type. These ships replaced the aging Liberties phased-out by mid-1980s. Niarchos was in the $8^{\text {th }}$ position for tankers over $6000 \mathrm{dwt}$, under five years old, in 1959 , with $59 \%{ }^{17}$. Onassis was in the $9^{\text {th }}$ position with $51 \%$.

In 1961 (aged 52), Niarchos placed orders in his own shipyard for 15 units of a 368,000 GRT total. He ordered one tanker of 26,000 GRT, (the "World Hope"), delivered in 1961, eight tankers T2 of 16,500 GRT, modified afterwards into dry cargoes, four tankers of 32,000 GRT, also modified into dry cargoes, and two of ${ }^{16}$ There were no Greek designs of ships at that time and ship plans had to be bought from abroad.

${ }^{17}$ Z. Zannetos, (1966), Oil tank ship rates, MIT Press. 
27,000 GRT, modified into two of 41,000 GRT dry cargoes. These modifications were made under the pressure of the tanker recession of 1959-1967, and the dry cargo recession of 1959-1973. In 1970, Niarchos ordered a VLCC of 200,000 GRT, called "Elena" after his daughter with Mrs. Ford. The ship was sold four years later. By 1963, only a tiny 107 ships belonging to Greeks had been constructed at Niarchos' shipyard.

In 1970 (aged 61), Niarchos' yard constructed a permanent berth of 250,000 dwt capacity, at a cost of $\$ 55 \mathrm{~m}$, the largest in the Mediterranean, and another one of similar size, later. By 1969 and 1970 the yard earned \$109 m. In 1985 (aged 76), the yard was sold to ETVA, a Greek state bank, for the low sum of \$11 $\mathrm{m}$, for the fear that the shipyard was going to be nationalized.

Niarchos was a citizen of USA, UK and Monte Carlo initially, and after 1967 also of Greece. Niarchos initially believed in the Greek flag, as other Greek shipowners did. The Greek flag was "protected" from ITF (sea labor union) and it could visit Russian ports, at that time, without obstacles. Niarchos' first company was established in New York in the 1950s and then transferred to London, due to problems created by the USA Government.

\subsection{Niarchos' Belief in Tankers and in the Demand for Oil}

Niarchos saw that the demand for oil was increasing globally, and that the oil majors were not as yet prepared to invest in their own tankers. The USA consumed 6000 barrels per day in 1950 and 14,000 in 1970, while Western Europe went from 1800 barrels per day to over 12,000. Japan, too, later, reached 4000 barrels per day.

Moreover, the global shipbuilding industry only delivered tankers of a $45 \mathrm{~m}$ dwt total, or 55\% of the ships built between 1946 and 1964. Niarchos, in 1955 (aged 46), followed an extensive shipbuilding program of large tankers of an increasing size, occupying first place in front of Ludwing and Onassis. Niarchos realized the benefits of economies of scale (over cost, and for profit) and the need of the USA and European shipyards for orders, and later of Japan.

Through his shipbuilding programs, Niarchos helped European shipyards to come back after their total destruction in the Second World War. He was clever enough to use time-charters with oil majors as a guarantee at the time of placing an order ${ }^{18}$, and in securing finance, as well.

At this time the location of refineries changed from places of extraction to places of consumption, where things were stable, and with no risk of nationalization, as happened in the Middle East. This favored tankers and product carriers. The USA economy emerged from the Second World War almost intact, with higher savings, which were invested in houses, cars and household appliances. Japan imported from the USA whatever was needed for its development. Coal was dethroned by oil.

However, the T2 tankers were not suitable for the distances created after the

${ }^{18}$ This is where Colocotronis Greek shipowner failed (Couper, A.D., 1999). 
Second World War. They had to compete with the emerging 50,000 dwt Suezmax type, which was able to pass through the Suez Canal. Later the Suezmax reached the 140,000-dwt size, with a cost of roughly $\$ 12$ per ton. The Aframax, $90,000 \mathrm{dwt}$, had a cost of roughly $\$ 15$ per ton and the VLCC, of 280,000 dwt, had a cost of $\$ 9.2$ per ton. Economies of scale were thus large and clear. A saving, of about $\$ 0.9 \mathrm{~m}$, added to profits, which could be secured by going from a Suezmax to a VLCC, and about $\$ 1.4 \mathrm{~m}$ going from an Aframax to a VLCC!!

\subsection{The Lack of Own Funds Was a Serious Obstacle to Fast Growth}

The cyclical nature of the shipping industry, shown before the Second World War, forced shipowners to buy ships using their own cash. This method did not allow companies to grow at the fast pace they wanted, as it has been shown in one of the case studies of Onassis (Goulielmos, 2021a, 2021b). If the owner could put down only $20 \%$ of the cash and fund $80 \%$ with a loan, then a fleet -this waycould grow five times faster. The loan could be secured by a simple mortgage, the preferred method, on the vessel to be built.

But still there was a credit risk. This could be passed on to the oil majors if the ship had a long-term time-charter, which served as a guarantee for bankers. Oil majors were reliable in paying hires. The banks then provided the majority of the money $(80 \%)$ to shipowners for the construction of vessels and the oil majors were paying the hires for 15 - 20 years ahead. Private tanker owners were more competitive than oil majors, and the oil majors transferred to hiring charters, where they had previously had their own transportation departments and fleets to satisfy their most valuable customers promptly (Lun et al., 2013: pp. 27-62).

\subsection{Niarchos: The Greek Flag and Greece (1959) (1970)}

In 1959 (aged 50), Niarchos launched the vessel "Princess Sophia", 71,282 GRT, under the Greek flag. Niarchos adopted the practice so that all vessels transporting crude oil to Greek refineries should fly the Greek flag. But 66 of his vessels were under the flags of Panama and Liberia. Niarchos was the first to use Liberia's registry, in early 1949, registering there his vessel "World Peace" of 18,072 GRT, built in USA (see image of a Liberian stamp).

Flags of convenience were preferred for reasons of taxation, and some of them were not delayed by ITF, as mentioned, with the exception of those under the flags of Honduras, Panama and Liberia, the so called "PanHonLib" flags. Also, national flags had a high degree of bureaucracy, higher expenses ${ }^{19}$ and worse terms of finance. These last facts were against building large ships. At that time, banks preferred to finance ships under flags of convenience!

In 1967 (aged 58), Niarchos was alarmed by the news that the UK would tax foreign shipping companies, and transferred three of his departments to Monte Carlo. This threat faded, and in 1968 he returned to London. However, he con-

${ }^{19}$ Papadakis said about $\$ 800$ per day for the Greek flag. 
vinced certain of his colleagues to transfer their offices to Greece. Niarchos ${ }^{20}$ then saw the repatriation of his office to Greece as advantageous, given that he had also a repair yard there. Repairs in Greece were cheaper, and a contact with ships' crew was possible. So, Niarchos returned to Greece in 1970.

\subsection{Niarchos during Dictatorship in Greece, 1967-1974}

In 1967, a dictatorship ruled Greece. In 1972, Niarchos established a factory to build diesel engines together with Fiat. The Government eventually subsidized the construction of ships by Greeks in Greece. The "Skaramagas shipyard" built ships of 37,000 GRT (bulk carriers). Niarchos ordered 12 dry cargoes ships to be delivered by the end of 1972 .

Instead of attracting the orders of other Greek shipowners to his shipyard, Niarchos ordered his own ships there ... In 1973, the market improved. Niarchos secured the lowest cost possible and he had priority in orders, so, he ordered six ships of 120,000 GRT each. The VLCCs in mid-1973 earned millions of dollars. These ships earned $\$ 1$ per barrel as a hire (roughly $\$ 2 \mathrm{~m}$ per year, in 1995; at W89 index units). The use of VLCCs became universal by 1969. Some of Niarchos' tankers were stuck with low time-charter hires before 1973.

\subsection{Niarchos and the VLCCs/ULCCs}

The extraordinary rise in the demand for oil led shipowners, and Niarchos, to large tankers. The Suez Canal and many ports could not allow calls from ULCCs and VLCCs at first, with the exception of the ports of Japan. VLCCs emerged in 1966-1968, but Greeks were not in the first seven shipowners, who ordered about $3.6 \mathrm{~m}$ dwt of them. Greeks were usually followers, and used to buy second hand vessels. They wanted other shipowners to burn their fingers first, but they also wanted to be competitive.

\subsection{Niarchos and the Recession after 1973}

In September 1973, freight rates were at their maximum. But in October 1973, a recession had struck and the oil trade fell, as the price of oil increased many times. Energy saving was then adopted as a common policy. A number of tankers were laid-up. New buildings stopped. Pre-existing time-charters saved Niarchos. He concentrated on cost reductions and staff cuts. This was the practice among Greek shipowners in a crisis. Greeks knew that their industry is cost-based and not freight-based.

In 1973, Niarchos took delivery of his first product carrier of 36,000 GRT. Then another followed, and three in 1974, and one dry cargo of 37,000, followed too by another six in the next 30 months. Niarchos then started scrapping his older ships. Between 1974 and 1982, $99.6 \mathrm{~m}$ dwt of tankers were scrapped, globally, with a maximum in 1982 (roughly $25 \mathrm{~m} \mathrm{dwt}^{21}$ ).

${ }^{20} \mathrm{He}$ was in favor of technology. In 1971 he had installed a satellite system of communications in all large tankers and the ULCCs he owned. This system indicated also the right course leading to savings in fuel. He also installed the first system of ITT, the "Aerospace 5001".

${ }^{21}$ Data given by Figure 12 for 1982, scrapping was $~ 55$ m Dwt. 


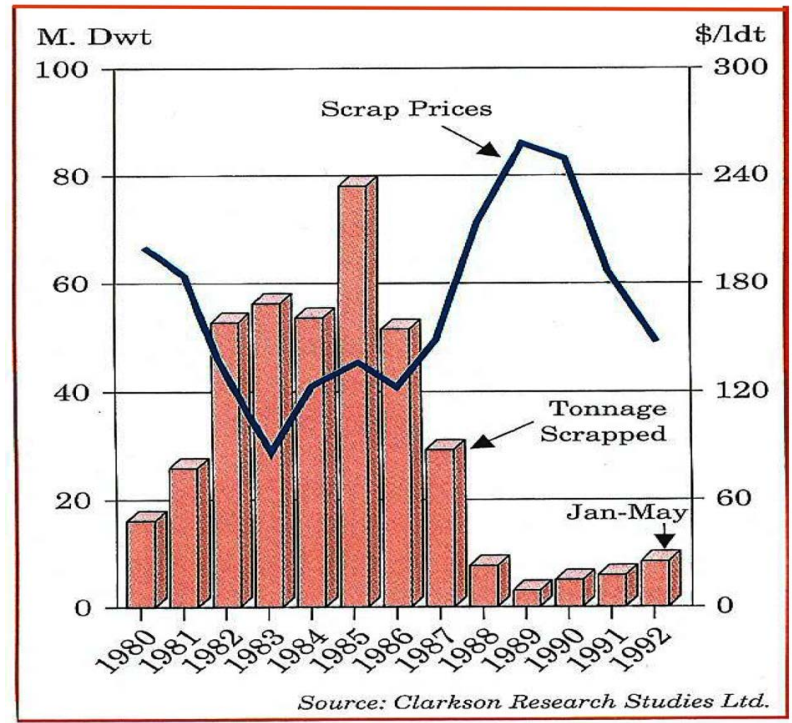

Figure 12. Scrapping and scrap prices between 1980 and 1992.

As shown, 1985 was the top year for scrapping with $80 \mathrm{~m}$ dwt. Scrap prices change in inverse proportion to the tonnage scrapped (supply). In 1989, the scrap price was at a peak of about $\$ 260$ per ldt (steel weight) compared with $\$ 80$ in 1983 (down by one third), which was the lowest price for the whole period 1980-1992.

Niarchos' remaining departments moved from the UK to Greece next. The UK crews were replaced by Greek. Niarchos believed in scrapping ships as they approached 12 years of age and over, as a rule, when a recession occurs. This was a British shipping practice as after 8 years of age ships had to pass the fourth 4 -year survey (at 12 years of age), which was very expensive (Goulielmos, doctoral thesis, 1974).

\subsection{Niarchos in 1975 (Aged 66)}

In 1974, Greece returned to democracy after 7 years of dictatorship. The 1975 Government, however, imposed additional taxation on shipowners, as this was the common practice of Greek Governments, including that of Prime Minister Venizelos, considering them as the only wealthy entrepreneurs. Greek-owned shipping used to be insured in the UK during the Second World War, and this insurance market remained intact during the war. The 1974 Prime Minister, Karamanlis, wanted to get $\$ 100 \mathrm{~m}$ from shipowners in the form of taxes. This meant 2.5 times the revenue from the rest of the country in 1975 .

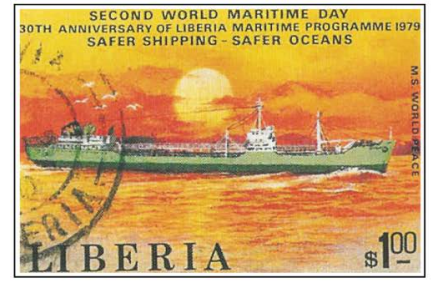

Niarchos resorted to Liberian flag (left) and signed-on foreign people as crews (from Korea and the Philippines). Liberia issued a special stamp with Niarchos' vessel M/T "World Peace" in 1979, to honor Niarchos. 


\subsection{Niarchos in 1973-1975}

The situation from 1973 to 1975 is presented in Table 7.

\subsection{Niarchos during the 1981-1987 Depression (Aged 72)}

At the end of 1981, Niarchos realized that shipping was no longer an industry where one could invest with a continuous success. Niarchos sold all his VLCCs, when the market improved in 1990, receiving $\$ 105 \mathrm{~m}$, with a profit of about $50 \%$. In fact, in March 1990, second hand prices indeed peaked for tankers (Figure 13).

The impact of age on vessel's value was great, especially after early 1990. A vessel built in 1970 (22 years of age), after March 1990, lost most of her value, while a vessel built in 1980 (12 years of age) retained her price. The VLCC "Exxon Valdez" accident in Alaska led the oil majors to use tankers of other owners for fear of a major marine accident. Niarchos bought a vessel of 300,000 dwt, ordered by "Amoco", and took delivery of her in 1993, with perfect automatic electronic equipment, at a low price. She was called: "Ocean Guardian".

Table 7. Events occurred between 1964 and 1988.

\begin{tabular}{cc}
\hline Year & Event \\
$1973-1975$ & Fall in global oil consumption \\
1976 & Recovery \\
$1979 ; 1981$ & Fall \\
1973 & Orders peaked, $200 \mathrm{~m} \mathrm{dwt}$ \\
1981 & Orders fell to $20 \mathrm{~m}$ dwt \\
$1980-1983$ & Crude oil trade fell by $20 \%$ \\
$1964-1983$ & Petroleum products rose by $49 \%$; $124 \%$ to $334 \mathrm{~m}$ tons \\
$1983-1988$ & Greek shipowners naturally turned to product carriers for the 1 st time
\end{tabular}

Source: author.

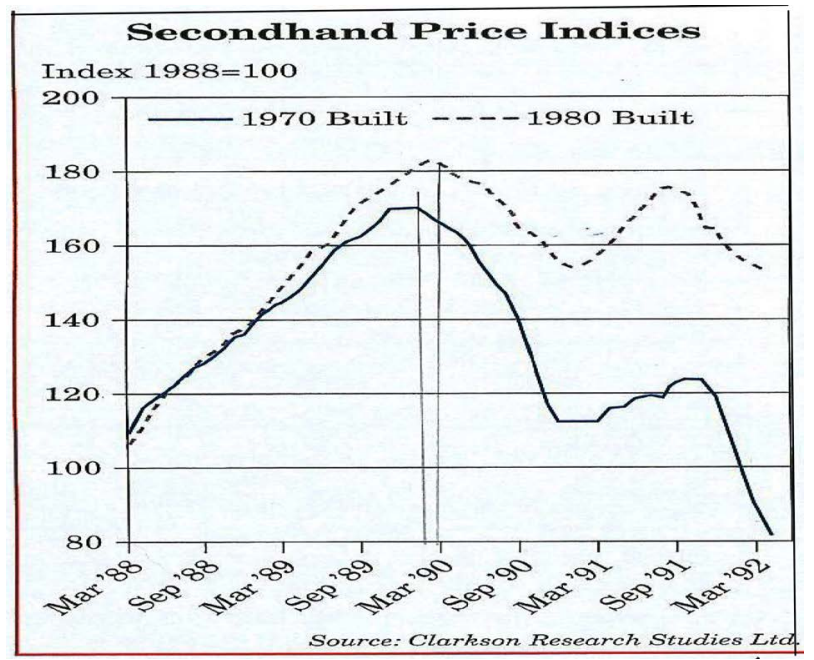

Figure 13. Second hand ship prices index, $1988=100$. Source: Stopford M (1992). 


\section{Concluding Remarks}

Niarchos required to be briefed about any decisions that had been taken by others in his company. He was a hard worker. He used to read fast, and study everything. He used to dictate his answers. He had a sense of time. He used to reward his aides with money or words. He did not rely on chance, and he wanted to be sure about everything. He was in favor of good public relations, as with the top officials of Fiat or Shell, and he liked to impress his high standing friends with his yacht "Kreoli" and his private island "Spetsopoula".

Niarchos believed in training of his staff, and he complained that he could not find capable aides to help him. He used to select staff by examining carefully his/her previous working experience. For example, he appointed the ex-general director of "Shell" to deal with tankers. He used experts to advise him over investments, like the English economist Kitchner, as well as others.

He preferred action to inaction. He acted here and now, today, rather than leaving it for tomorrow, and he looked for effectiveness. He stood by his opinion and it was difficult to convince him to change his mind. He was not a socialite, but kept his distance from others. He was conservative, usually in a permanent bad mood, and laconic by nature.

He envied Onassis, whose steps watched and followed carefully (in preferences, decisions, and selections). Niarchos was tough with those that had to pay to him freights and hires and were in delay. He had a sharp mind, was a perfectionist, with a good memory, and a fast decision-maker. His management was personal. He liked to spend money, but with the utmost care. He was demanding about increasing results, and he had sudden outbursts that created tension for everybody.

He liked accurate replies from the start and disliked errors and corrections afterwards. He wanted to be first and invincible. He was tough if someone cheated him. He finally acquired whatever he wanted. He had a natural ability to choose the right investment, and to determine its upper price, for which was also right.

Niarchos lived 21 years (1975-1996) longer than Onassis and faced the tanker shipping recessions in 1974, 1975, 1979. So, Niarchos had harder times as a shipowner. The freight rates for tankers were cyclical, but peaked 4 times in the period from 1947 to 1957. The 1958-1967 decade was bad for freight rates. In the period between 1968 and 1987, freight rates peaked again four times.

Niarchos was successful as a shipowner, devoting $20 \%$ of his $\$ 400$ m estate to a foundation upon his death. Although shipping markets finally disappointed him, unlike Onassis who was disappointed and completely destroyed by the death of his son.

Niarchos was succeeded by his elder son ${ }^{22}$ Philippos, from Evgenia Livanos, who had a fortune of $\$ 2.5 \mathrm{~b}$ in 2016 , according to Forbes, and who is a co-president of the "Stavros Niarchos Cultural Foundation" ${ }^{23}$ ". While Onassis

${ }^{22}$ Spyros, Maria and Constantinos (he passed away in 1999; born in 1962), are the other 3 children of Niarchos from Evgenia Livanos.

${ }^{23}$ This foundation quickly received a great publicity due to TV and the frequent benevolent actions. 
failed as a father, Niarchos failed as a husband, marrying six wives, five women, and his tankers making them six.

Overall, Niarchos based his business on the right horse, which was oil, until the end of 1973. He also based it on economies of scale. His unlucky star faced a number of oil recessions and depressions in 1974, and thereafter, because he failed to balance his fleet over the various shipping sectors, tankers, product carriers and dry-cargoes, so that he could spread his risk, among types, sizes and ages. History teaches that a shipping crisis does not hit all ships, of all sizes and ages, equally.

His great competitive advantage was to have his own shipyard for his own orders and at his disposal. So, he had ships when he needed them, at priority and at a low price, built from cheap steel that he produced. He tried to cut costs, crew and staff to save about $20 \%$ of his outgoings when facing shipping depressions, but, like all shipowners, he could not foresee them or be ahead of them. Coming from a tough area (Mani), he was a tough personality, especially with his wives.

\section{Conflicts of Interest}

The author declares no conflicts of interest regarding the publication of this paper.

\section{References}

Besanko, D., Dranove, D., Shanley, M., \& Schaefer, S. (2013). Economics of Strategy (6th ed.). International Student Version, Singapore: Wiley.

Bilas, R. A. (1967). Microeconomic Theory: A Graphical Analysis. New York: McGraw-Hill Book Co.

Couper, A. D. (1999). Voyages of Abuse: Seafarers Human Rights \& International Shipping, with Others. London: Pluto Press.

Frangoulis, G. K. (2001). Stavros Niarchos: My Experience from Working with Him. Athens: Fereniki Editions.

Goulielmos, A. M. (1974). A Vintage Model Approach to Some Problems of Shipping Economics. Unpublished Doctoral Thesis, Uxbridge: Brunel University.

Goulielmos, A. M. (2009). Is History Repeated? Cycles and Recessions in Shipping Markets, 1929 and 2008. Shipping \& Transport Logistics, 1, 329-360. https://doi.org/10.1504/IJSTL.2009.027679

Goulielmos, A. M. (2018). The Nature of Economic Turbulence: The Power Destructing Economies, with Application to Shipping. Modern Economy, 9, 5.

Goulielmos, A. M. (2020). The Investment Strategy and the Growth Policy of the Greek Shipowners Revealed, 1946-2020. Modern Economy, 11, 1858-1886.

https://doi.org/10.4236/me.2020.1111125

Goulielmos, A. M. (2021a). Managing Shipping Companies, the Way Their Pioneers Did: The Case-Studies of Vafias N Family and Aristotelis S. Onassis. Modern Economy, 11, 2156-2182. https://doi.org/10.4236/me.2021.121013

Goulielmos, A. M. (2021b). Managing Shipping Companies, the Way Their Pioneers Do: The Case-Studies Aristotelis S. Onassis II and Angeliki Frangou. Modern Economy, 12, 
247-273. https://doi.org/10.4236/me.2021.121013

Henderson, J. M., \& Quandt, R. E. (1958). Microeconomic Theory: A Mathematical Approach. Int. Student Edition, New York: McGraw-Hill Book Co, Inc.

Kapsis, N. (2005). Shipping Capital in Mainland of Greece. Athens: Kerkyra Editions.

Kavussanos, M. G., \& Visvikis, I. D. (2006). Shipping Freight Derivatives: A Survey of Recent Evidence. Maritime Policy \& Management, 33, 233-255.

https://doi.org/10.1080/03088830600783152

La Rocco, L. A. (2012). Dynasties of the Sea: The Shipowners and Financiers Who EXpanded the Era of Free Trade. Stamford, CT: Marine Money, Inc.

Lorange, P. (2020). Innovations in Shipping. Cambridge: Cambridge University Press. https://doi.org/10.1017/9781108347945

Lun, V. Y. H., Hilmola, O.-P., Goulielmos, A. M., Lai, K.-H., \& Cheng, T. C. E. (2013). Oil Transport Management. Berlin: Springer. https://doi.org/10.1007/978-1-4471-2921-9

McCleery, M. (2013). The Shipping Man: Adventures in Ship Finance (2nd ed.). Singapore: Marine Money.

Mpatis, E. (1999). Portraits in Blue Background: Persons Who Wrote History in the Shipping of the 20th Century. FINATEC S.A. Editions. (In Greek)

Stopford, M. (1992). Shipping Cycles and Ship Finance, a Special Overview. International Financial Law Review, Special Supplement, August.

Stopford, M. (2009). Maritime Economics (3rd ed.). London: Routledge. https://doi.org/10.4324/9780203891742

Theotokas, I., \& Harlaftis, G. (2009). Leadership in World Shipping. Greek Family Firms in International Shipping. London: McMillan Editions. https://doi.org/10.1057/9780230233539

Zannetos, Z. S. (1966). The Theory of Oil Tankship Rates. Product of His Doctoral Thesis, Cambridge, MA: MIT Press. 